\title{
Correlation, age and significance of Turonian Chalk hardgrounds in southern England and northern France: the roles of tectonics, eustasy, erosion and condensation.
}

\author{
Andy Gale \\ School of Earth and Environmental Sciences, University of Portsmouth, Burnaby Building, \\ Burnaby Road, Portsmouth P013QL UK
}

\begin{abstract}
The stratigraphy and correlation of Middle and Upper Turonian hardgrounds developed around the margins of the Anglo-Paris Basin in southern England (Chalk Rock) and Normandy (Tilleul Hardgrounds) are reassessed using microcrinoid stratigraphy. The Chalk Rock was formed by two, discrete events - an earlier, erosional or non-depositional hiatus that cuts out much of the Middle Turonian in Dorset and Wiltshire (Ogbourne Hardground) and extends across the English Channel to Normandy as the Tilleul Hardgrounds, and a later, strongly condensed succession of Late Turonian age, developed from the Chilterns westwards across to Wiltshire (Fognam Farm, Blount's Farm, Hitch Wood Hardgrounds). Where the two events intersect, in Wiltshire, the Lewes Chalk is very thin. The lower event is of lower Romaniceras ornatissimum Zone age, and is a local representation of a short-lived, globally identifiable eustatic low. The condensation associated with the upper part of the Chalk Rock can be attributed to relative non-subsidence across a region of relatively shallow basement in the western part of its development. No evidence has been found of tectonic inversion in the Turonian along the Purbeck-Isle of Wight structure, but very local, penecontemporaneous movement on the Litton Cheney Fault in Dorset generated a conglomerate of older Cretaceous (Albian, Cenomanian, Turonian) rocks redeposited within the Middle Turonian. The base of the Lewes Chalk Formation is strongly diachronous across southern England, younging from west to east. The formation of the Chalk Rock and equivalent deposits in France can be related to an eustatic low during Middle and Late Turonian times. The development of individual Chalk Rock hardgrounds is possibly caused by minor eustatic lows, driven by the long eccentricity cycle (405Kyr).
\end{abstract}

andy.gale@port.ac.uk 


\section{Introduction}

The Chalk Rock of central southern England (Hertfordshire, Buckinghamshire, Berkshire, Wiltshire, Dorset) comprises a distinctive succession, 1 - 4 m thick, of mature, strongly lithified and mineralized (glaucony, carbonate-fluorapatite, pyrite, iron oxides) hardgrounds (Bromley and Gale, 1982) which developed across the northern part of the Anglo-Paris in the Middle and Late Turonian, and is a highly condensed equivalent of the basinal successions to the south and east, where approximately 60 - 70 metres of soft to nodular, often marly, chalks were deposited in Sussex and Normandy (Mortimore 1983, 1986; Mortimore and Pomerol 1987; Gale 1996, 2019). The Chalk Rock hardgrounds were named, individually characterised and correlated by Bromley and Gale (1982). Much of the interest in the Chalk Rock has been concentrated on the uppermost hardground, the Hitch Wood, which has locally yielded abundant ammonites of the Subprionocyclus neptuni Zone (Wright 1979; Kennedy 2019) and diverse sponges, aragonitic bivalves and gastropods.

Various attempts have been made to correlate between the Chalk Rock and the expanded basinal succession developed to the south and east in Sussex, Kent and east Hampshire. The basinal succession contains a number of distinctive, thin, marl beds, named by Mortimore (1986), some of which have a volcanic geochemical signature (negative europium anomaly), which can be traced into northeast England, and eastwards to northern Germany (Wray 1999). Some individual marls possess trace element geochemical fingerprints that enable their identification (Wray and Gale 1994; Wray 1999). These marls are progressively occluded and lost onto the surfaces of individual Chalk Rock hardgrounds in the passage from the basin into condensed areas.

It should be possible to identify the precise (relative) age of hardground surfaces in the basinal succession and use this to quantify the detailed patterns of condensation. This information will enable an evaluation of the mechanism of formation of the Chalk Rock. This was attempted by Wray and Gale (1994), but the identification of many marls in critical regions remained uncertain. Gale (1996) proposed a correlation of the Turonian chalks of the UK, based on detailed logging of rhythmic beds in conjunction with the identification of important fossil markers and Wray's (1999) geochemical correlation. In particular, he used rhythmic couplets of chalk- marl to develop a detailed stratigraphy and correlation of the New Pit Chalk in the Isle of Wight, Dorset and Wiltshire. A key finding was the presence of a major disconformity on the surface of the basal hardground of the Chalk Rock, the Ogbourne 
Hardground in the south west, on which the New Pit and Glynde Marls are cut out. Gale (1996) argued that the primary control on hardground formation was eustasy, and identified five sequences and their component systems tracts in the Turonian of the UK.

The alternative viewpoint, adopted by Mortimore (1986, 2011, 2018) and Mortimore et al. (2001), and subsequently by the BGS (Hopson 2005; Woods and Aldiss 2004; Woods 2015), is to treat the Chalk Rock as a locally condensed member representing the lower part of the Lewes Nodular Chalk Formation. Critically, Mortimore et al. (2001) identified the basal marker of the formation, Glynde Marls 1-4, to be present beneath the Chalk Rock in western localities such as Beggar's Knoll, Wiltshire and Shillingstone, Dorset (Mortimore 2011, 2018). However, Gale (1996) had previously shown that the lowest hardground of the Chalk Rock, the Ogbourne Hardground, cuts down erosionally far into the New Pit Chalk in the Isle of Wight, Dorset and Wiltshire, and that the succession containing the New Pit and Glynde Marls, represented by up to $45 \mathrm{~m}$ of chalk in the centre of the basin, is cut out on the surface of this hardground. In this model, the onset of nodularity, marking the base of the Lewes Chalk Formation, and widely mapped by BGS, is strongly diachronous from east to west.

Gale's (1996) correlation was criticized at the time by anonymous referees on account of the lack of biostratigraphical control and subsequently by Mortimore et al. (2001) largely because it contradicted the model of the synchronous onset of nodularity at the base of the Lewes Chalk, and because they identified the Glynde and New Pit Marls beneath the Chalk Rock in Wiltshire and Dorset. Recently, microcrinoid stratigraphy has been used to provide a high-resolution correlation of Turonian chalks of the Anglo-Paris Basin (Gale 2019), and is here used to test the correlations proposed by Wray and Gale (1994), Gale (1996) and Mortimore et al. (2001). The resulting model is used to reassess the eustatic framework of Gale (1996), and to evaluate the suggestion by Mortimore $(1986,2011,2018)$ that penecontemporaneous inversion along the Purbeck-Isle of Wight structure was an important control on Turonian and later Cretaceous sedimentation. The study was carried out across southeastern England and northwestern France (Fig. 1).

The occurrence of a major hiatus within the Middle Turonian has been identified in numerous countries across three continents (North America, Eurasia, Africa - KTu4 - Haq and Huber 2016), but lacks precise dating in many regions. It is indicated to fall within the Collignoniceras woollgari Zone in Europe, but as used by these authors, this zone is over 2 Myr 
in duration - nearly half the total length of the Turonian, and thus temporally imprecise. This hiatus is represented within the lower suite of Chalk Rock hardgrounds, and a new collation of ammonite data provides evidence of its precise dating.

\section{Lithostratigraphy}

Chalk lithostratigraphical nomenclature has been formalized by the British Geological Survey (Hopson 2005), and the Turonian Stage is represented by, successively, the Holywell, New Pit and the lower part of the Lewes Chalk Formations. The locally developed Chalk Rock Member forms the lowest division of the Lewes Chalk. High-resolution lithostratigraphical control is provided by thin, laterally extensive marl beds (Mortimore 1983,1986) some of which have a volcanic origin (Wray 1999).

\section{Biostratigraphy}

\subsection{Traditional macrofossil zones}

The macrofossil zonation of the English Chalk follows Rowe (1900), who divided what is now recognized as the Turonian into three zones: Rhynchonella cuvieri (now replaced by Mytiloides mytiloides); Terebratulina lata; and Holaster (now Plesiocorys) planus (see review by Gale and Cleevely 1989). Their correspondence to other biostratigraphical schemes is shown in Fig. 2. Woods (2015 fig. 2) used a combination of the traditional macrofossil zones and inoceramid species to recognize six divisions within the Turonian of southern England, not recognized here.

\subsection{Ammonites}

Ammonites provide a high resolution, geographically extensive means of correlation within the Middle and Upper Turonian (Robaszynski et al. 2014; Amédro et al. 2018), and two parallel zonal schemes have been established, one based on the family Collignoniceratidae, the other on the Acanthoceratidae, notably the genus Romaniceras. Species of this genus provide excellent zonal markers within the Middle and Upper Turonian substages, and permit definition of successive $R$. kallesi, $R$. ornatissimum, $R$. mexicanum and $R$. deverianum Zones, each less than 0.5 Myr in duration. Some of these zones have been recognized in the south west of the Paris Basin (Amédro et al. 2018) and widely across southern and central Europe, North Africa, the Middle East, Central and North America (Mexico, Texas, California), Japan, 
India and Madagascar (Robaszynski et al. 2014). However, they are dominantly Tethyan species, and only two of them ( $R$. ornatissimum, $R$. deverianum) are present, as very rare fossils, in the UK (Wright and Kennedy 1981).

Species of the family Collignoniceratidae are more common in the chalk facies of southern England and northern France, including the long-ranging but geographically widespread Middle Turonian Collignoniceras woollgari (Europe, North and Central America, North Africa, Turkmenistan, Russia, Japan and Australia) and species of the genus Subprionocyclus (Europe, Russia, North Africa, Madagascar, Japan), which is generally acknowledged to be of Late Turonian age (Robaszynski et al. 2014). The precise relationship between the Romaniceras and collignoniceratid zones is debatable; it is certain that C. woollgari co-occurs with R. kallesi, R. ornatissimum and R. mexicanum (Robaszynski et al. 2014) and extends down to the base of their underlying Kamerunoceras turoniense Zone. The relationship between $R$. deverianum and Subprionocyclus is more contentious, because the species have not been observed to co-occur at the same level. It is clear that in the UK Subprionocyclus first occurs beneath the lowest known occurrences of $R$. deverianum (Gale 1996, confirmed by Kennedy 2019), both beneath the Glynde Marl at Fognam Farm (S. cf. hitchinensis) and at the level of the Southerham Marls at Dover (S. branneri). Romaniceras deverianum occurs between the Southerham and Bridgwick Marls in southern England (Fig. 2; Gale 1996).

The diverse ammonite fauna of the Chalk Rock (Wright 1979; Kennedy 2019) mostly comes from the Hitch Wood Hardground fossil bed, which is a remanié deposit, including two elements, an older S. neptuni Zone fauna, and a younger Hyphantoceras flexuosum fauna, probably indicative of the Prionocyclus germari Zone. The older of these faunas occurs as indigenous fossils between the Bridgewick and Lewes Marls at Dover. Finally, the uppermost Turonian (zone uncertain) is recognized at Dover from a single find of Barroisiceras haberfellneri (Gale and Woodroof 1981). The known occurrences of ammonites, and the inferred zonation, is given in Fig. 2.

\subsection{Inoceramid bivalves.}

Inoceramid bivalves provide high resolution, interregional correlation in the Upper Cretaceous, and a zonation for the Turonian had been published in part by Walasczczyk and Cobban (2000). The oldest Middle Turonian fauna, with Mytiloides hercynicus and M. 
subhercynicus, occurs between the Lulworth and Round Down Marls (Gale 1996; Mortimore 1997). Above, successive Inoceramus species appear; the smaller I. apicalis appears $2 \mathrm{~m}$ beneath the Round Down Marl, and the larger I. lamarcki extends from the New Pit Marl 2 up to the Caburn Marl (Mortimore et al. 2001; Weise et al. 2017). A detailed zonation for the Upper Turonian is based on species of Inoceramus, Mytiloides and Cremnoceramus (Fig. 2; Wood et al. 2004; Wiese et al. 2018).

\subsection{Turonian Stage and Substage boundaries.}

The base of the Turonian Stage is formally defined at the base of Bed 86 in the Bridge Creek Limestone in the Pueblo Reservoir State Park Recreation Area, west of Pueblo, Colorado (Kennedy et al. 2000, 2005). The GSSP is marked by the first occurrence of the ammonite Watinoceras devonense. In the UK, this level was identified at Holywell, Eastbourne, Sussex, at the level of Meads Marl 4 in the Holywell Formation (Gale et al. 2005).

The base of the Middle Turonian has been informally taken in Bed 120 of the Bridge Creek Limestone in the Rock Canyon Anticline, at Pueblo, Colorado, marked by the first occurrence of the ammonite Collignoniceras woollgari (Bengston 1996; Kennedy et al. 2000). The base of the Upper Turonian has never been agreed upon (Bengston 1996), but is here provisionally taken at the first occurrence of the inoceramid bivalve Inoceramus perplexus at the level of the Caburn Marl in southern England, which is approximately coincident with the Caburn Event, a small positive excursion in $\partial^{13} \mathrm{C}$ (Jarvis et al. 2006).

\subsection{Microcrinoids}

Gale (2019) established a microcrinoid (Roveacrinida) zonation for the Turonian of the Anglo-Paris Basin, elements of which can be recognized as far east as the Czech Republic and south to Morocco. Fourteen Turonian zones (TuR1-14) are recognizable in the Chalk of the Anglo-Paris Basin (Figs 2, 3). These zones are of short duration in the Lower and Middle Turonian, and provide a useful new biostratigraphical tool. 


\section{Carbon isotope stratigraphy}

The presence of numerous positive and negative excursions in the bulk chalk ${ }^{13} \mathrm{C}$ curve for the Turonian was demonstrated by Jenkyns et al. (1994). Subsequently, Gale (1996) named two positive excursions as the Pewsey and Hitch Wood Events. A detailed nomenclature for carbon-isotope excursions was provided by Jarvis et al. (2006). These are shown in Fig. 2. Some have been identified as far afield as the Western Interior Basin of the USA (Joo and Sageman 2016) and Japan (Takashima et al. 2019), as illustrated by Jarvis et al. (2015).

\section{Methods}

Sections were logged, and samples of $1 \mathrm{~kg}$ were collected at $0.5-1 \mathrm{~m}$ spacing, and processed using the technique with $96 \%$ acetic acid and anhydrous copper sulphate described by Gale (2019). The residues were graded and the $0.5-4.0 \mathrm{~mm}$ fraction was picked with a binocular microscope.

\section{Localities studied}

The litho- and microcrinoid stratigraphy of the basinal Turonian successions of Eastbourne and Dover were described by Gale (2019). The details of other localities studied in this work are included in the Appendix.

\section{Discussion}

7.1. Age of chalk beneath the Ogbourne Hardground in Dorset, Isle of Wight, Wiltshire and Berkshire, UK

The microcrinoid biostratigraphy for key localities in the Isle of Wight (Culver, Compton), Dorset (Ballard Cliff, Piddletrenthide, Shillingstone), Wiltshire (Beggars Knoll, Cley Hill) and Berkshire (Fognam Farm) demonstrates progressive westwards cut-down of the surface lithified by the Ogbourne Hardground into the New Pit Chalk (Fig. 4 and Appendix) and this fully supports the original correlation of Gale (1996). On the Isle of Wight and the Dorset 
coast, the lower $5-7 \mathrm{~m}$ of TuR8 are preserved beneath the Ogbourne Hardground, $0.75 \mathrm{~m}$ at Shillingstone, $1.5 \mathrm{~m}$ at Beggar's Knoll, and $8 \mathrm{~m}$ at Fognam Farm. At Piddletrenthide, Dorset, and Cley Hill, Wiltshire, the Ogbourne rests upon the lower part of TuR7, and only the basal part of the New Pit Chalk is preserved.

The thickness of the New Pit Chalk (e.g. Newell et al. 2018) in the south-west (Hampshire, Isle of Wight, Dorset, Wiltshire) is largely controlled by erosion and/or non-deposition associated with the Ogbourne Hardground surface. Additionally, the New Pit Chalk thins towards the Ogbourne Platform, as shown by a transect between Winchester, Burghclere and the Faircross borehole (Gale 1996 fig. 6), in which the interval between New Pit Marl 1 and Glynde Marl 1 thins from $18 \mathrm{~m}$ at Winchester to $6 \mathrm{~m}$ at Burghclere. The degree of induration and mineralization of the Ogbourne Hardground reflect the relative length of exposure of the surface. Thus, at Fognam Farm, Berkshire, where the hardground represents minimum condensation, it is nodular and weakly glauconitised. In contrast, at Beggar's Knoll, and at all localities in Wiltshire and Dorset, where it represents a considerable hiatus, it is massively cemented, and strongly mineralized by glauconite and iron minerals (Bromley and Gale 1982). The surface of the Ogbourne Hardground occludes New Pit Marls in north Hampshire, Berkshire and east Wiltshire (Fig. 9B), but the Glynde Marl, overlying the Pewsey Hardground, extends a little further to the west. The Ogbourne surface eventually cuts further down to the west to remove the Round Down Marl (Fig. 9B).

In west Wiltshire, at Cley Hill, west of Warminster, the base of the Lower Coniacian zone CoR1 occurs above above the Ogbourne Hardground, which here lithifies TuR7 chalk (Appendix Fig. 1). The hiatus represented by the Chalk Rock here represents most of the Middle and all of the Upper Turonian, equivalent to about $70-80 \mathrm{~m}$ in the basinal Sussex coast successions (Figs. 4,5). The Lewes Chalk is shown to be very thin in this region and to the north of it (Newell et al. 2018 fig. 15). On the Devon coast, the Cenomanian and Lower Turonian are highly condensed (Jarvis and Woodroof 1982) and represented by a thin succession with numerous hardgrounds. By contrast, the overlying flinty chalks of the New Pit Formation (Beer Roads Member of Jarvis and Woodroof 1981) demonstrates the presence of a considerably expanded Middle Turonian succession including microcrinoid zones TuR7-R9 (Appendix Fig. 8), and confirms identification of two prominent marl beds (Common Hill Marl, Smuggler's Cove Marl) as representing New Pit Marls 1 and 2, respectively. There is no representation of the Ogbourne Hardground or the associated hiatus. The expanded 
succession perhaps represents a channel infill, similar to that developed in the Campanian chalks of the Isle of Wight (Gale et al. 2013).

7.2 Age of chalk on the Normandy coast beneath the Tilleul Hardgrounds

An equivalent condensation of the Middle Turonian to that in southern England occurs in Normandy, where the coastal sections between St Martin-Plage, east of Dieppe, Sennevillesur-Fecamp, Tilleul Plage and Tancarville demonstrate progressive westwards thinning and condensation of the Lower and Middle Turonian towards the Armorican Massif (Fig. 7; Juignet and Breton 1991, 1994). The results of microcrinoid sampling demonstrate the precise nature of this condensation. The expanded basinal succession of St Martin-Plage is developed in a marly chalk facies, and contains the same marker marls as in southern England (Mortimore and Pomerol 1987; Wray 1999; Gale 2019). A full succession of microcrinoid zones is present (TuR1 - TuR14), although the uppermost Turonian is somewhat thinner than that developed in Sussex (Gale 2019). Some $70 \mathrm{~km}$ to the WSW, at Senneville-sur-Fecamp (Appendix Fig. 9), the Lower and Middle Turonian have thinned considerably, and a group of well indurated and heavily mineralized hardgrounds are present in the Middle Turonian, and these extend to the west and south. They were called the Tilleul Hardgrounds by Kennedy and Juignet (1974), and the lowest of these, here called Tilleul 0, rests upon chalks which belong to TuR7 (Fig. 7). T0 is immediately overlain by a thin development $(0.5 \mathrm{~m})$ of TuR8 and TuR9 (1 m), surmounted by the Tilleul Hardground 1, which is overlain by a thick development of TurR10. Samples from $1 \mathrm{~m}$ beneath the Southerham Marl 1 (Kennedy and Gale 2015) upwards yield a TuR11 fauna. At Tilleul Plage (Fig. 7, Appendix Fig. 10), $20 \mathrm{~km}$ to the WSW, the succession has thinned further, and Tilleul 0 lithifies zone TurR7, which is here $3 \mathrm{~m}$ thick, and underlain by a thin development of TuR6.

The three Tilleul Hardgrounds correlate with the Ogbourne Hardground of the UK succession, but represent a slight expansion; the hiatus overlying the hardgrounds is significantly smaller, and zones TuR8 and TuR9 are thin but present, except at Tancarville. However, the erosional surface on Tilleul 0 corresponds exactly in age to the Ogbourne Hardground surface in the UK, and represents the same event, and has eroded down into chalk of TuR7 age across Haute Normandie. In the UK, the Ogbourne surface only erodes this far down at Piddletrenthide and Winterbourne Abbas in Dorset and Cley Hill, Wiltshire (compare Figs. 4 and 7). 
In conclusion, there is a major hiatus in the Middle Turonian of the northwestern part of the Anglo-Paris Basin, represented by the surface of the Ogbourne Hardground (UK) and Tilleul Hardground 0 (Normandy). This can be identified as falling beneath the New Pit 1 Marl, and significantly above the Round Down Marl. This level can be dated to the lower part of the Romaniceras ornatissimum Zone, within the Inoceramus apicalis Zone and within microcrinoid zone TuR8.

\subsection{The upper Chalk Rock; Late Turonian condensation}

The upper part of the Chalk Rock, comprising the Fognam Farm, Blounts Farm and Hitch Wood Hardgrounds (Fig. 6; see also Bromley and Gale 1982), is developed in the Chilterns and extends westwards through Buckinghamshire, Bedfordshire, Berkshire, north Hampshire, Oxfordshire, Wiltshire and into north Dorset (Figs 8, 9C). The group of hardgrounds converge to form a metre-thick unit of chalkstone in the Chilterns - the "Henly Rock" of Hill (1886), and expands rapidly into thick, marly successions to the north east, with the progressive loss of the Fognam Farm, Blounts Farm and Hitch Wood Hardgrounds (Fig. 6). The Southerham Marl and Caburn Marl appear in the expanded succession developed in Hertfordshire and Bedfordshire, respectively, above the Fognam Farm Hardground and the Blounts Farm Hardground. The upper Chalk Rock succession remains thin (1.5 - $3 \mathrm{~m})$ across Berkshire and Oxfordshire, but condenses dramatically in the western part of the outcrop (Cley Hill, Wiltshire), where it is probably represented by $0.1 \mathrm{~m}$ of lithified chalk (Bromley and Gale 1982 fig. 16). The pattern of sedimentation of the upper part of the Chalk Rock is one of progressive condensation into areas of thin development, as seen across the Chilterns (Fig. 6), which contrasts with the downcutting, erosive event represented by the surface of the Ogbourne Hardground (Figs 4, 5). There are no known basement structures underlying the "Henly Rock" development (Bromley and Gale 1982),

The consistent alternation of major Chalk Rock hardgrounds with marls (Pewsey-Glynde Marl; Fognam Farm-Southerham Marl; Blounts Farm-Caburn Marl; Hitch Wood-Bridgewick Marls) is suggestive of a rhythmic repetition, probably moderated by sea-level changes. 
7.4. Turonian cyclicity, timescale and hardground development.

There is a clear cyclicity expressed in the Turonian chalks of the Anglo-Paris Basin, which is developed as decimetre-scale chalk:marl couplets in the Lower Turonian and lower part of the Middle Turonian (Holywell and New Pit Formations); these were used to construct a timescale based on the model that these are precession cycles (Gale 1996). In the Middle and Upper Turonian, larger-scale cyclicity $(10-15 \mathrm{~m})$ is represented as an alternation of marlier units, including discrete marl beds and weakly nodular chalks. In the basinal successions, the marls comprise, successively, New Pit, Glynde, Southerham, Caburn, Bridgewick and Lewes (Mortimore 1986). The nodular chalks pass into the hardgrounds of the Chalk Rock, and, with condensation, the marls occlude onto the surfaces of individual hardgrounds (Bromley and Gale 1982; Gale 1996).

Tentative identification of 405Kyr cycles in the Cenomanian and Turonian, using timeseries analysis combined with radiometric dates was made by Batenburg et al. (2016, Fig. 3) using the orbital solution of Laskar et al. (2011). This identified the Cenomanian-Turonian boundary as most probably falling within cycle 232, and identified named carbon-isotope excursions in the Turonian as corresponding with individual 405kyr cycles. This approach is extended upwards here, in order to estimate the frequencies of larger-scale Turonian cycles, based upon:

1) The orbital solution for $405 \mathrm{Kyr}$ cycles provided by Laskar et al. (2011).

2) Cyclostratigraphical age for the base of the Middle Turonian from Meyers et al. (2012).

3) Radiometric dates from the Western Interior Basin (Gradstein et al. 2012 Appendix 2).

4) Correlation of Western Interior ammonite zones into the Anglo-Paris Basin succession in order to position the radiometric dates. The most important of these are the horizon of the Prionocyclus hyatti Zone, which falls beneath the FO of Romaniceras deverianum (Robaszynski et al. 2014; see Fig. 2 herein), and the Scaphites nigricollensis Zone (underlying the P. germari Zone, identified in Germany and France, Robaszynski et al. 2014; see Fig. 2 herein), and thus equivalent to the upper part of the Subprionocyclus neptuni Zone.

5) The model that marly units represent eccentricity maxima, and nodular chalks minima (Batenburg et al. 2012). 
The result of this approach is shown in Fig. 10, and although tentative, a broad correspondence between $405 \mathrm{Kyr}$ cycles and nodular chalk:marly chalk alternations represented in the Anglo-Paris Basin can be identified. This figure also underlines the considerable condensation represented by the Hitch Wood Hardground, already recognised from biostratigraphy (see above).

The sequence stratigraphical model of Gale (1996), which identified four sequences in the Turonian of the Anglo-Paris Basin, is rejected, because it failed to identify the significance of the hardground:marl alternations and did not recognise the considerable condensation associated with the Hitch Wood Hardground. Rather, Turonian sedimentation appears to have been driven by sea-level changes related to the long eccentricity (405Kyr) cycle, and condensation took place over structural highs during sea level lowstands. The Chalk Rock formed in response to a longer-term eustatic low widely described from the Late Turonian (Hancock and Kauffman 1979; Haq et al. 1988), commencing within the Middle Turonian.

\subsection{Significance for regional lithostratigraphy in the UK}

The base of Lewes Chalk Formation is marked by the supposedly synchronous onset of nodular chalk deposition, above Glynde Marl 1 (Mortimore 1986; Mortimore et al. 2001; Woods and Aldiss 2004), although Hopson (2005) allowed some minor variation in the level at which nodularity commences. Thus, at Dover, in the south-east, This synchoneity is evidently not true, as the base of the Lewes Chalk becomes progressively older westwards, as the mid-Turonian disconformity, represented by the Ogbourne Hardground surface, cuts out the upper part of the New Pit Chalk, including, successively, the Glynde, New Pit and Round Down Marls (Fig. 9B). The top of the New Pit Chalk of Berkshire, Wiltshire and Dorset, is of different ages in different localities (TuR7 and TuR8), and is cemented to form the Ogbourne Hardground. The age of the chalk overlying the Ogbourne Hardground also varies significantly across Dorset and Wiltshire, from Middle Turonian (e.g. TuR10 in Dorset) to Early Coniacian (CoR1) at Cley Hill, Wiltshire (Figs 4, 5).

The lithostratigraphy developed for the Chalk of southern England (Bristow et al. 1987; Rawson et al. 2001; Hopson 2005) may facilitate remotely sensed mapping, but the macrofossil biostratigraphy employed to identify and correlate units (Mortimore et al. 2001; 
Mortimore 2011; Woods 2015) is clearly insufficiently refined to allow the identification of diachronous boundaries or to recognize the presence of significant disconformities within the succession. The new microcrinoid biostratigraphy provides useful additional information that permits this.

\subsection{Tectonic control}

There is a broad relationship between the depth to Variscan basement (Chadwick 1993 fig. 1b) and development of the Chalk Rock in the south-west part of the outcrop (Fig. 9D), as the thickness of the unit decreases onto shallower basement. It is notable that the thinnest succession of Turonian Chalk studied, at Cley Hill in Wiltshire, is only 8km distant from outcropping Paleozoic rocks of the Mendips (Bromley and Gale 1982). The Chalk Rock does not appear to be affected by the east-west Pewsey Fault, movement on which may be responsible for a thicker Lewes Chalk succession to the south (Newell et al. 2018 fig. 15). The isopachs of the eastern part of the Chalk Rock outcrop do not show any relationship to the depth of the buried London Platform, the depth contours of which run east-west, or the dominantly east-west orientation of deep faults (Chadwick et al. 2005 fig. 85). The Chalk Rock isopachs in the eastern part of the outcrop have a NNW-SSE trend, and the succession thickens rapidly to the east of the domal structure around Henley (Fig. 9D). The Henley dome does not appear to correspond to any basement structures (Bromley and Gale 1982). The rapid thickening of the Lewes Chalk to the east is also shown in the Lewes Chalk isopach map (Newell et al. 2018 fig. 15).

There have been various claims that Late Cretaceous inversion of the Isle of WightPurbeck fault system affected Chalk sedimentation, most notably in the Turonian to Campanian succession at Culver Cliff on the Isle of Wight (Mortimore 1986, fig. 25). More recently, Mortimore (2018) has claimed that there is local thinning and erosion of the uppermost New Pit Chalk at White Nothe and Lulworth, related to early inversion of the Purbeck structure. Detailed logging of the Turonian sections along the Isle of Purbeck provides no evidence of any intra-Turonian thinning related to structures; the New Pit Chalk varies between 17 to $19 \mathrm{~m}$ in thickness between White Nothe and Ballard Head (Gale 1996). The identification of Glynde Marl 4 at White Nothe (Mortimore 2018) is in error, because this level is absent on the erosional surface that extends across the entire western chalk outcrop. 
The New Pit Chalk thins significantly to the west in Dorset, and is $8 \mathrm{~m}$ thick at Piddletrenthide and $10 \mathrm{~m}$ at Shillingstone, as the Ogbourne surface erodes down more deeply (Fig. 4). This thinning is not related to penecontemporaneously active structural features.

Striking evidence of penecontemporaneous movement on a fault in Dorset is the development of a conglomerate composed of earlier Cretaceous material (Upper Greensand, Grey Chalk Group, Holywell Chalk) at the base of the Lewes Chalk in the region of Winterbourne Abbas and Litton Cheney (Robbie, 1950; Wilson et al. 1958). Recent reexposure of the section west of Loscombe Farm, Coombe Road, south of Winterbourne Abbas shows the presence of a 3 m thick conglomerate composed of large (up to $15 \mathrm{~kg}, 0.5 \mathrm{~m}$ maximum dimension) clasts of Upper Greensand, marly chalk from the Grey Chalk Subgroup, and phosphatised fossils derived from the Basement Bed of the Chalk. The underlying chalk yields a fauna of TuR7 age (Appendix, Figs. 4, 5), but the microcrinoid fauna of the upper part of the section consists entirely of reworked Cenomanian and Lower Turonian species, indicative of a Late Cenomanian (CeR5) and Early Turonian (TuR1,2) age. The local thickness of the formations represented in the conglomerate indicates that a minimum displacement of $70 \mathrm{~m}$ took place on an easterly extension of the Litton Cheney Fault (Butler 1999), probably downthrown to the south as a normal fault.

\subsection{The mid-Turonian eustatic disconformity}

The presence of a major disconformity within the Middle Turonian has been identified widely in North America and Europe, but imprecisely dated, because of problems of correlation with ammonites (see above). Thus, Haq and Huber (2016) indicated the break to fall within the Collignoniceras woollgari Zone in Europe, but this zone is over 2 Myr in duration - nearly half the total length of the Turonian, and thus temporally imprecise. Here I present a brief review of the distribution and dating of this event (Fig. 11).

Western Interior Basin, USA

In the Western Interior Basin, Joo and Sageman (2014) identified a major break at the boundary between the Fairport Shale and Codell Sandstone members of the Carlile Shale Formation, including all of the Collignoniceras praecox Zone. On the basis of their carbon isotope correlation, this falls between the Round Down and Glynde Events (see also Jarvis et 
al. 2015 fig. 8), and is thus precisely coincident with the mid-Turonian break found in southern England.

Samurois, southwestern Paris Basin, France

In this region, the Tuffeau de Saumur, of $R$. kallesi Zone age, is terminated with a hardground, and overlain by glauconitic sands, the Sables de Saint-Hilaire, of $R$. ornatissimum Zone age (Amédro et al. 2018).

Barranca, Spain

In the Izurzdiaga 1 section, Küchler (1998) identified two hardgrounds at the base of the $R$. ornatissimum Zone (Fig. 5, Pl. 1.2), which, together with the underlying R. kallesi Zone, is strongly reduced in thickness. A mineralized hardground is also developed at the Puenteday section, Burgos (pers. obs.) within the lower part of the R. ornatissimum Zone.

Agadir Basin, Morocco

The section on the coast at Taghazout, $20 \mathrm{~km}$ north of Agadir, shows the presence of a hardground at the top of the Lower - Middle Turonian Calcaires de Kasbah d'Agadir, overlain by successively, microcrinoid faunas of TuR8 and TuR10. This is correlative with the Ogbourne Hardground of the Anglo-Paris Basin (Gale unpublished).

\section{Conclusions}

A new stratigraphy, based on microcrinoids, provides support for the Turonian correlation model of Gale (1996), and shows that a significant hiatus is developed on the surface of the Ogbourne Hardground in Wiltshire and Dorset, which involves most of TuR8, all of TuR9, and includes the Round Down, New Pit and Glynde Marls. The base of the Lewes Chalk Formation is thus strongly diachronous from east to west, as the Ogbourne Hardground erodes down into and lithifies older chalks within the New Pit Formation to the west. An equivalent erosive event is present in Haute Normandie, on the French coast, as the Tilleul Hardgrounds cut down to older levels in the Middle Turonian. However, the detailed patterns of erosion and sediment preservation are different on each side of the Channel. 
The disconformity associated with the Ogbourne Hardground can be dated to the lower part of the range of the ammonite Romaniceras ornatissimum, which has a nearly global distribution (Robaszynski et al. 2014). An equivalent break is present widely in North America, Europe, is here recorded from North Africa, and probably represents the hiatus described by Haq and Huber (2016) as KTu4. The cause of this eustatic event remain enigmatic, but Haq and Huber did not rule out a brief glacigenic episode close to the peak of the Cretaceous greenhouse.

The eustatic model for Turonian chalk sedimentation of Gale (1996), which identified five sequences in the Turonian, is not supported by the new evidence. Rather, the formation of the Chalk Rock involved two distinct processes; an earlier, erosional event, represented by the Ogbourne Hardground, and later progressive condensation, as marker marls occluded onto hardground surfaces in condensed regions. The rhythmic pattern of sedimentation can be related to eustatic control by the long eccentricity (405kyr) cycle (Fig. 10).

There is no support for the suggestion that Turonian inversion of the Isle of WightPurbeck structure influenced sedimentation (Mortimore 2018), as thickness patterns across the structure are not controlled by the basement faults. The major control on Chalk Rock development was probably differential non-subsidence over relatively shallow basement (Bromley and Gale 1982). However, dramatic evidence of intra-Middle Turonian faulting is shown at Winterbourne Abbas in Dorset, where penecontemporaneous movement on the Litton Cheney Fault resulted in the formation of a conglomerate of Albian, Cenomanian and Turonian material.

Acknowledgements

This paper is dedicated to the memory of Richard Granville Bromley, whose enthusiasm stimulated the author's interest in the Chalk Rock and lead to publication of Bromley and Gale (1982) and Gale (1996). Richard's friendliness, humour and scientific rigour are sadly missed. I would like to thank landowners and managers who permitted access to sites, especially Mr. Sturrock (Loscombe Farm) and Nigel Osman (Beggar's Knoll), and Christine Hughes (Biological Sciences, University of Portsmouth) for access to the SEM. I would like to thank the referees, Profs Ian Jarvis and David Wray, for most useful comments. 


\section{References}

Amédro, F., Matrion, B., and Robaszynski, F. 2018. Stratotype Turonien. Museum nationale d’histoire naturelle, Paris; Biotope, Meze, 416pp. (Patrimonie géologique, 8).

Batenburg, S.J., Sprovieri, M., Gale, A.S., Hilgen, F.J., Husing, S., Laskar, J., Liebrand, D., Lirer, F., Orue-Etxebarria, X., Pelosi, N. and Smit, J. 2012. Cyclostratigraphy and astronomical tuning of the Late Maastrichtian at Zumaia (Basque country, northern Spain). Earth and Planetary Science Letters 359-360, 264-278.

Batenburg, S.J., De Vleeschouwer, D., Sprovieri, M., Hilgen, F.J., Gale, A.S., Singer, B.S., Koeberl, C., Coccioni, R., Claeys, P. and Montanari, A. 2016. Orbital control on the timing of oceanic anoxia in the Late Cretaceous. Climates of the Past, 12, 1995-2009.

Bengtson, P. 1996. The Turonian Stage and substage boundaries. Bulletin de l'Institut Royal des Sciences Naturelles de Belgique. Sciences de la Terre. 66, (supplément) 69-79.

Bristow, C.R., Mortimore, R.M. \& Wood, C.J. 1997. Lithostratigraphy for mapping the Chalk of southern England. Proceedings of the Geologists' Association, 108, 292-315.

Bromley, R.G. and Gale, A.S. 1982. The lithostratigraphy of the English Chalk Rock. Cretaceous Research, 3, 273-306.

Butler, M. 1999. The geological history of the southern Wessex Basin - a review of new information from oil exploration. In: Underhill, J.R. (ed.), Development, Evolution and Petroleum Geology of the Wessex Basin. Geological Society Special Publication no. 133, 67-87.

Chadwick, R.A. 1993. Aspects of basin inversion in southern Britain. Journal of the Geological Society, London, 150, 311-322.

Chadwick, R.A. and Evans, D.J. 2005 A seismic atlas of southern Britain: images of subsurface structure. Nottingham, UK, British Geological Survey, 196pp. (British Geological Survey Occasional Publication, 7).

Gale, A.S., 1996. Turonian correlation and sequence stratigraphy of the Chalk in southern England. In: Hesselbo, S.P., Parkinson, D.N. (Eds.), Sequence Stratigraphy in British Geology. Geological Society Special Publication, No. 103, pp. 177-195. 
Gale, A.S. 2019 (in press). Microcrinoids (Echinodermata: Articulata: Roveacrinida) from the Cenomanian-Santonian chalk of the Anglo-Paris Basin: taxonomy and biostratigraphy. Revues de Paléobiologie.

Gale, A.S. and Cleevely, R. 1989. Arthur Rowe and the zones of the White Chalk of the English coast. Proceedings of the Geologists' Association, 100, 419-431.

Gale, A.S., Kennedy, W.J., Voigt, S. and Walaszczyk, I. 2005. Stratigraphy of the Upper Cenomanian-Lower Turonian Chalk succession at Eastbourne, Sussex, UK: ammonites, inoceramid bivalves and stable carbon isotopes. Cretaceous Research, 26, 460-487.

Gale, A.S., Surlyk, F., Anderskouv, K., 2013. Channelling versus inversion: Origin of condensed Upper Cretaceous chalks, eastern Isle of Wight, UK. Journal of the Geological Society 170, 281290.

Gale, A.S. and Woodroof, P. 1981. A Coniacian ammonite from the "Top Rock" in the Chalk of Kent. Geological Magazine, 118, 557-560.

Gradstein, F.M., Ogg, J.G., Schmitz, M.D. and Ogg, G.M. 2012. Geologic Timescale 2012. Elsevier BV, 1130pp.

Hancock, J.M. and Kauffman, E.G. 1979. The great transgressions of the Late Cretaceous. Journal of the Geological Society, London, 136, 175-186.

Haq, B.U. and Huber, B. 2016. Anatomy of a eustatic event during the Turonian (Late Cretaceous) hot greenhouse climate. Science China Earth Sciences, doi: 10.1007/s11430-0160166-y.

Haq, B.U., Hardenbol, J. and Vail, P. R. 1988. Mesozoic and Cainozoic Chronostratigraphy and Cycles of Sea-Level Change. In: Sea-Level Changes - an Integrated Approach. SEPM Special Publications no. 42, 71-107.

Hill, W. 1886. On the beds between the Upper and Lower Chalk of Dover, and their comparison with the Middle Chalk of Cambridgeshire. Quarterly Journal of the Geological Society of London, 42, 232-248. 
Hopson, P.M. 2005. A stratigraphical framework for the Upper Cretaceous Chalk of England and Scotland with statements on the chalk of Northern Ireland and the UK Offshore Sector. BGS Research Report RR/05/01.

Jarvis, I., Woodroof, P.B., 1984. Stratigraphy of the Cenomanian and basal Turonian (Upper Cretaceous) between Branscombe and Seaton, S E Devon, England. Proceedings of the Geologists' Association 95, 193-215.

Jarvis, I., Gale, A.S., Jenkyns, H.C. and Pearce, M. A. 2006. Secular variation in Late Cretaceous carbon isotopes: a new $\mathrm{d} 13 \mathrm{C}$ carbonate reference curve for the Cenomanian-Campanian (99.6-70.6Ma). Geological Magazine, 143, 561-608.

Jarvis I, Trabucho-Alexandre J, Gröcke DR, Uličný D, Laurin J. 2015. Intercontinental correlation of organic carbon and carbonate stable isotope records: evidence of climate and sea-level change during the Turonian (Cretaceous). The Depositional Record, 1, 53-90.

Jenkyns, H.C., Gale, A.S. and Corfield, R. 1994. Carbon- and oxygen-isotope stratigraphy of the English Chalk and Italian Scaglia and its palaeoclimatic significance. Geological Magazine, 131, 1-34.

Joo, Y. J. and Sageman, B.G. 2014. Cenomanian to Campanian carbon isotope chemostratigraphy from the Western Interior Basin, USA. Journal of Sedimentary Research, $84,529-542$.

Juignet, P. and Breton, G. 1991. Mid-Cretaceous sequence stratigraphy and sedimentary cyclicity in the western Paris Basin. Palaeogeography, Palaeoclimatology, Palaeoecology, 91, 197-218.

Juignet, P. and Breton, G. 1994. Stratigraphie, rhythmes sédimentaires et eustatisme dans les craies turoniennes de la region de Fécamp (Seine-Maritime) France. Bulletin trimestrielle de la Société Géologique de Normandie et des Amis du Muséum du Havre, 81, 55-81.

Kennedy, W.J. 2019 (in press). The Ammonoidea of the Upper Chalk. Part 1.

Palaeontographical Society (Monograph). 
Kennedy, W.J. and Gale, A.S. 2015. Late Turonian ammonites from Haute-Normandie, France. Acta Geologica Polonica, 65, DOI: 10.1515/agp-2015-0021.

Kennedy, W.J. and Juignet, P. 1974. Carbonate banks and slump beds in the Upper Cretaceous (Upper Turonian-Santonian) of Haute-Normandie, France. Sedimentology, 21, 1-42.

Kennedy, W.J., Walaszczyk, I., Cobban, W.A., 2000. Pueblo, Colorado, U.S.A., candidate Global Boundary Stratotype Section and Point for the base of the Turonian Stage of the Cretaceous, and for the base of the Middle Turonian Substage, with a revision of the Inoceramidae. Acta Geologica Polonica, 50, 295e334.

Kennedy, W.J., Walaszczyk, I., Cobban, W.A., 2005. The global Boundary Stratotype Section and Point for the base of the Turonian Stage of the Cretaceous: Pueblo, Colorado, U.S.A. Episodes, 28, 93-104.

Küchler, T. 1998. Upper Cretaceous of the Barranca (Navarra, northern Spain); integrated litho-, bio- and event stratigraphy. Part 1: Cenomanian through Santonian. Acta Geologica Polonica, 48, 157-236.

Laskar, J., Fienga, A., Gastineau, M., and Manche, H. 2011. La2010: a new orbital solution for the long-term motion of the Earth. Astronomy and Astrophysics, 532, A89.

Meyers, S.R., Siewert, S.E., Singer, B.S., Sageman, B.B., Condon, D.J., Obradovitch, J.D., Jicha, B.R. and Sawyer, D.A. 2012. Intercalibration of radioisotopic and astrochronologic time scales for the Cenomanian-Turonian boundary interval, Western Interior Basin, USA. Geology 40, 7-10.

Mortimore, R.N. 1983. The stratigraphy and sedimentation of the Turonian-Campanian in the Southern Province of England. Zitteliana, 10, 27-41.

Mortimore, R.N., 1986. Stratigraphy of the Upper Cretaceous White Chalk of Sussex. Proceedings of the Geologists' Association 97, 97-139.

Mortimore, R.N. 1997. The Chalk of Sussex and Kent. Geologists' Association Guide no. 57. 139 pp. 
Mortimore, R.N., 2011. A chalk revolution: what have we done to the Chalk of England? Proceedings of the Geologists' Association 122, 232-297.

Mortimore, R.N. 2018. Late Cretaceous stratigraphy, sediments and structure: Gems of the Dorset and East Devon Coast World Heritage Site (Jurassic Coast), England. Proceedings of the Geologists' Association D0I.org/10.1016/j.pgeola.2018.05.008.

Mortimore, R.N., Pomerol, B., 1987. Correlation of the Upper Cretaceous White Chalk (Turonian to Campanian) in the Anglo-Paris Basin. Proceedings of the Geologists' Association 98, 97-143.

Mortimore, R.N., Wood, C.J., Gallois, R.W., 2001. British Upper Cretaceous Stratigraphy, Geological Conservation Review Series, No. 23. Joint Nature Conservation Committee, Peterborough.

Newell, A.J., Woods, M.A., Farrant, A.R., Smith, H., and Haslam, R.B. 2018. Chalk thickness trends and the role of tectonic processes in the Upper Cretaceous of southern England. Proceedings of the Geologists' Association, 129, 610-628.

Rawson, P.F., Allen, P., Gale, A.S., 2001. The Chalk Group - a revised lithostratigraphy. Geoscientist 11, 21.

Robaszynski, F., Amédro, F., Devalque, C. and Matrion, B. 2014. Le Turonien des Massifs d'Uchaux et de la Ceze (S.E. France). Mémoires de la Classe des Sciences Academie Royale de Belgique. Brussels. 197pp., 48 pls.

Robbie, R.A. 1950. The Chalk Rock at Winterbourne Abbas, Dorset. Geological Magazine, 87, 209-213.

Rowe, A.W.E. 1900. The Zones of the White Chalk of the English coast. 1, Kent and Sussex. Proceedings of the Geologists' Association, 16, 289-368.

Takashima, R., Nishi, H., Yamanaka, T., Orihashi, Y., Tsujino, Y., Quidelleur, X., Hayashi, K., Sawada, K., Nakamura, H. and Ando, T. 2019. Establishment of Upper Cretaceous bio- and carbon isotope stratigraphy in the northwest Pacific Ocean and radiometric ages around the Albian/Cenomanian, Coniacian/Santonian and Santonian/Campanian boundaries. 
Newsletters on Stratigraphy, DOI: 10.1127/nos/2019/0472

Walaszczyk, I., Cobban, W.A. 2000. Inoceramid faunas and biostratigraphy of the Upper Turonian - Lower Coniacian of the Western Interior of the United States. Special Papers in Palaeontology no. 64. 118pp.

Wiese, F., Zobel, K. and Mortimore, R.N. 2018. Intrinsic processes control late Turonian calcareous dinoflagellate cyst assemblages - A case from the Sussex chalk (England). Cretaceous Research, 87, 206-217.

Wilson, V., Welch, F.B.A., Robbie, J.A. and Green, G.W. 1958. The Geology of the country around Bridport and Yeovil. Memoirs of the Geological Survey of Great Britain. 239pp.

Wood, C.J., Walasczcyk, I., Mortimore, R.N. and Woods, M.A. 2004. New observations on the inoceramid biostratigraphy of the higher part of the Upper Turonian and the TuronianConiacian boundary transition in Poland, Germany and the UK. Acta Geologica Polonica, 54, 541-549.

Woods, M.A. 2015. Applied palaeontology in the Chalk Group: quality control for geological mapping and modelling and revealing new understanding. Proceedings of the Geologists' Association, 126, 777-787.

Woods, M.A. and Aldiss, D.T. 2003. The stratigraphy of the Chalk Group of the Berkshire Downs. Proceedings of the Geologists' Association 115, 249-265.

Wray, D.S. 1999. Identification and long-range correlation of bentonites in TuronianConiacian (Upper Cretaceous) chalks of northwest Europe. Geological Magazine, 136, 361371.

Wray, D.S. and Gale, A.S. 1994. Geochemical correlation of marl bands in Turonian chalks of the Anglo-Paris Basin. In; Hailwood, E.A. and Kidd, R.B. (eds),

High Resolution Stratigraphy. Geological Society Special Publication 70, 211-226.

Wright, C.W. 1979. The ammonites of the English Chalk Rock. Bulletin of the British Museum (Natural History), Geology, 31, 281-332. 
Wright, C.W. and Kennedy, W.J. 1981. The Ammonoidea of the Plenus Marls and the Middle Chalk. Palaeontographical Society (Monograph), 148pp.

Figures.

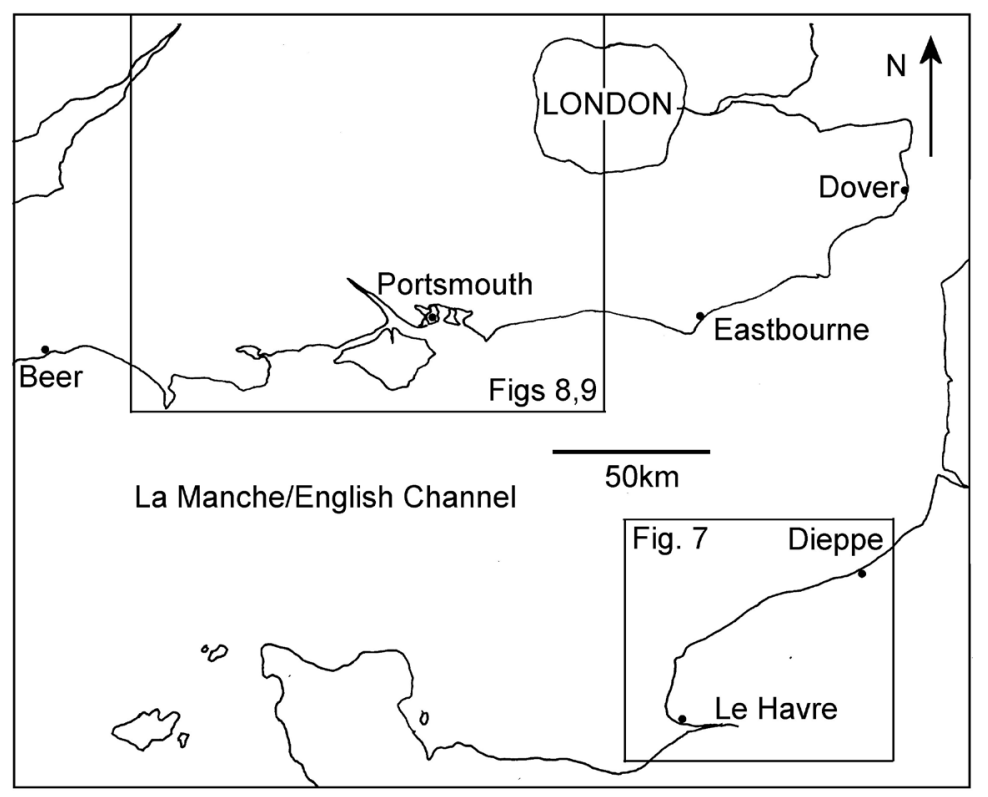

Fig. 1 Map of southern England and Normandy, France, to show position of locality maps shown in Figs 4-7. 


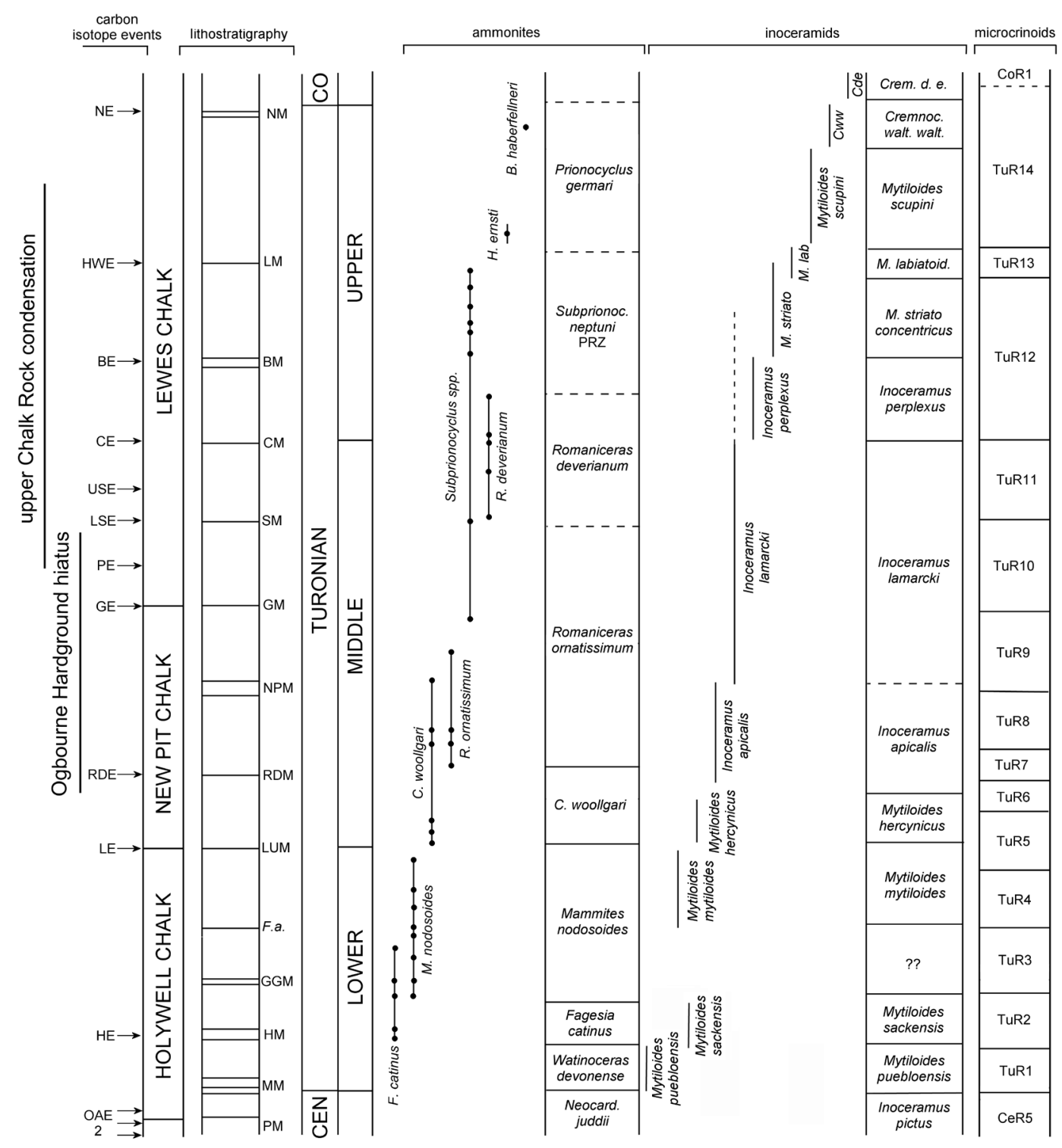

Fig. 2. Stratigraphical scheme for the Turonian Stage. C-isotope events after Jarvis et al. (2006); HE, Holywell Event; LE, Lulworth Event; RDE, Round Down Event; GE, Glynde Event; PE, Pewsey Event; LSE, USE, lower and upper Southerham Events; CE, Caburn Event; BE, Bridgewick Event; HWE, Hitch Wood Event; NE, Navigation Event. Lithostratigraphy, marker beds; PM, Plenus Marls; MM, Meads Marls; HM, Holywell Marls; GGM, Gun Gardens Marls; F.a., Filograna avita Bed; LUM, Lulworth Marl; RDM, Round Down Marl; NPM, New Pit Marls; GM, Glynde Marls; SM, Southerham Marls; CM, Caburn Marl; BM, Bridgewick Marls; LM, Lewes Marl; NM, Navigation Marls. Ammonite zones after Gale (1996) with modifications. Inoceramid zones after Walaszczyk and Cobban (2000) with comments from I. Walasczcyk (pers comm). Microcrinoid zones after Gale (2019). This figure is not to scale. 


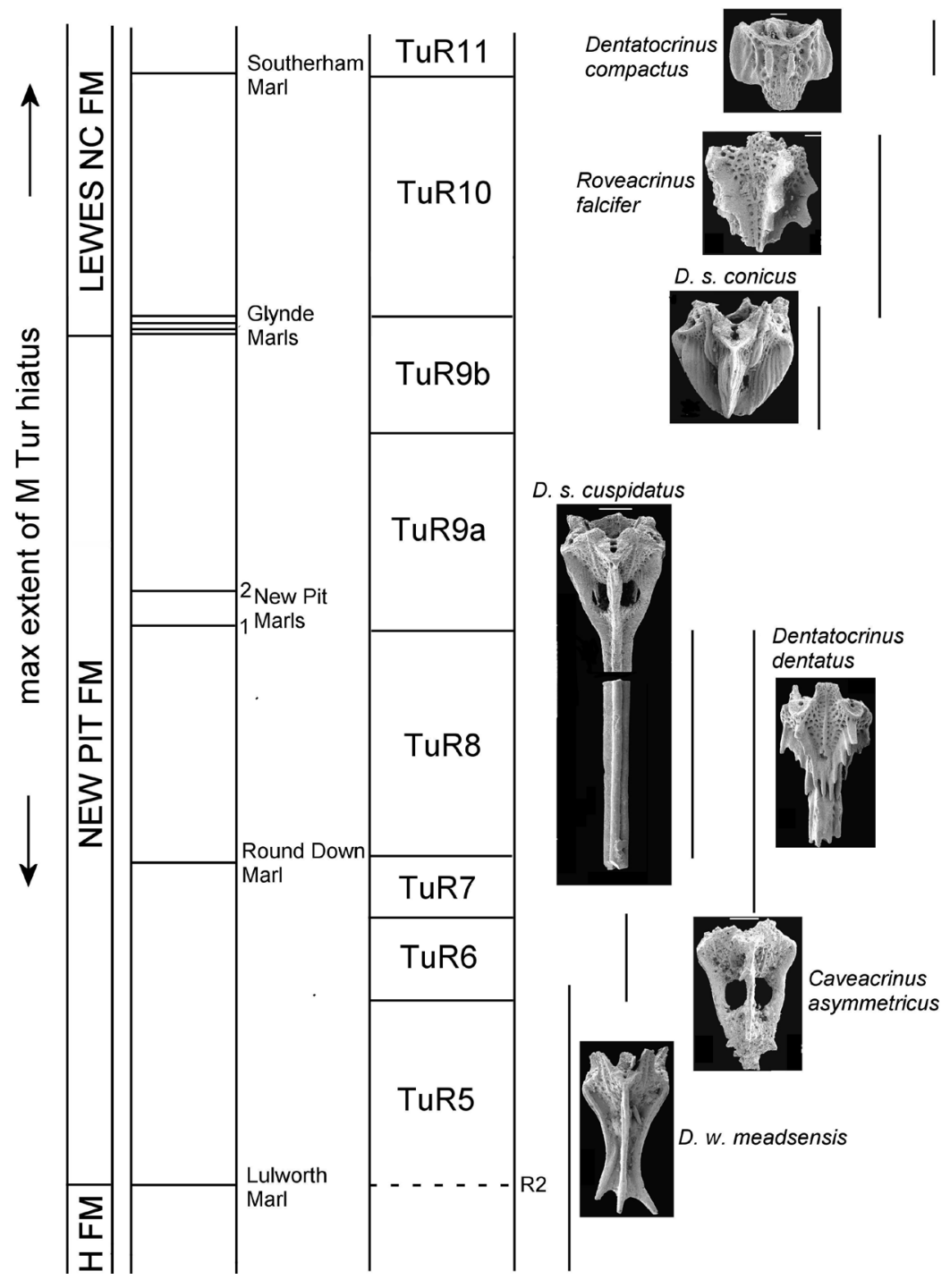

Fig. 3 Middle Turonian microcrinoid stratigraphy, after Gale (2019). The ranges of key species in the expanded basinal successions (Sussex, Dieppe) are indicated. See Gale 2019, figs 6,11,17 for detailed records. Abbreviations; Drepanocrinus westfalicus forma meadsensis; Drepanocrinus striatulus forma cuspidatus; Drepanocrinus striatulus forma conicus. There is no vertical scale. Zone TuR9a is characterized by a microcrinoid fauna which lacks D. s. cuspidatus D. dentatus and D. s. conicus, but includes longer-ranging species. 


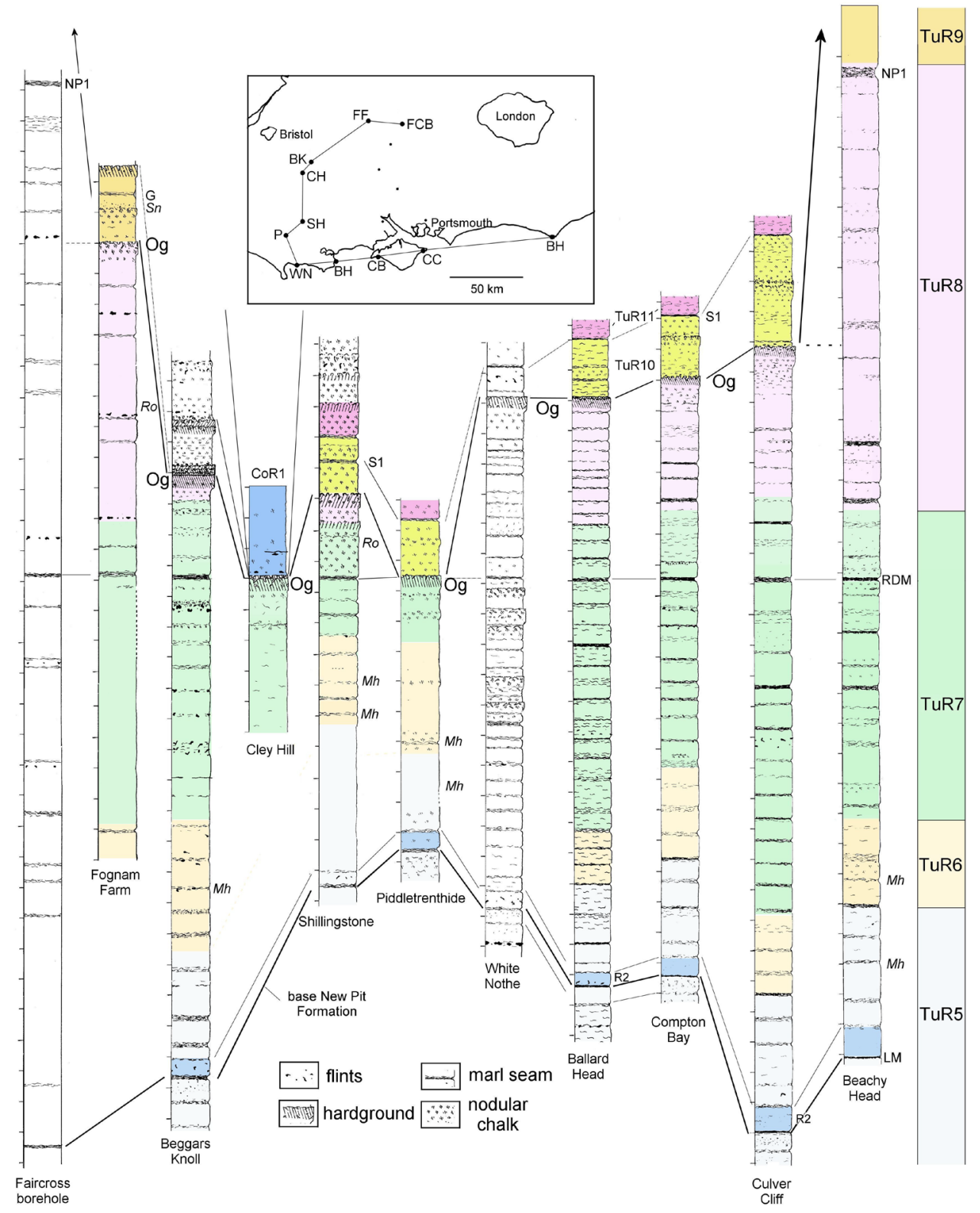

Fig. 4. Middle - Upper Turonian correlation across southern England. The erosional surface at the top of the Ogbourne Hardground $(\mathrm{Og})$ cuts down into the New Pit Chalk to the west, resting upon successively older horizons - microcrinoid zones TuR8 and TuR7. The New Pit and Glynde Marls (in Zone TuR9) are absent through erosion or non-deposition across the western region. The Ogbourne Hardground is overlain by a thin development of TuR10 in localities $2-7$, but at CH (Cley Hill) Early Coniacian chalks (CoR1) rest upon TuR7, and a large part of the Middle, and all of the Upper Turonian is absent. At Fognam Farm (FF) the Ogbourne Hardground is more weakly developed, and a reasonable thickness of TuR8 is preserved beneath it, but the New Pit Marls are missing on the erosional surface. Localities; BH, Beachy Head, Sussex. CC, Culver Cliff, Isle of Wight.CB, Compton Bay, Isle of Wight. BH, Ballard Head, Dorset. WN, White Nothe, Dorset. P, Piddletrenthide, Dorset. SH, Shillingstone, 
Dorset. CH, Cley Hill, Wiltshire. BK, Beggars Knoll, Wiltshire. FF, Fognam Farm, Berkshire. FCB, Faircross borehole, Berkshire. Abbreviations in italics refer to important fossil finds; $M h$, Mytiloides hercynicus; R.o., Romaniceras ornatissimum; S, Subprionocyclus. Abbreviations for marls are; LM, Lulworth Marl; RDM, Round Down Marl; NP1, New Pit 1; S1, Southerham 1. Og, Ogbourne Hardground. R2, Roveacrinus Bed 2 of Gale (1996). See also Fig. 8 for locality details, and Table 1. Vertical scale in metres.

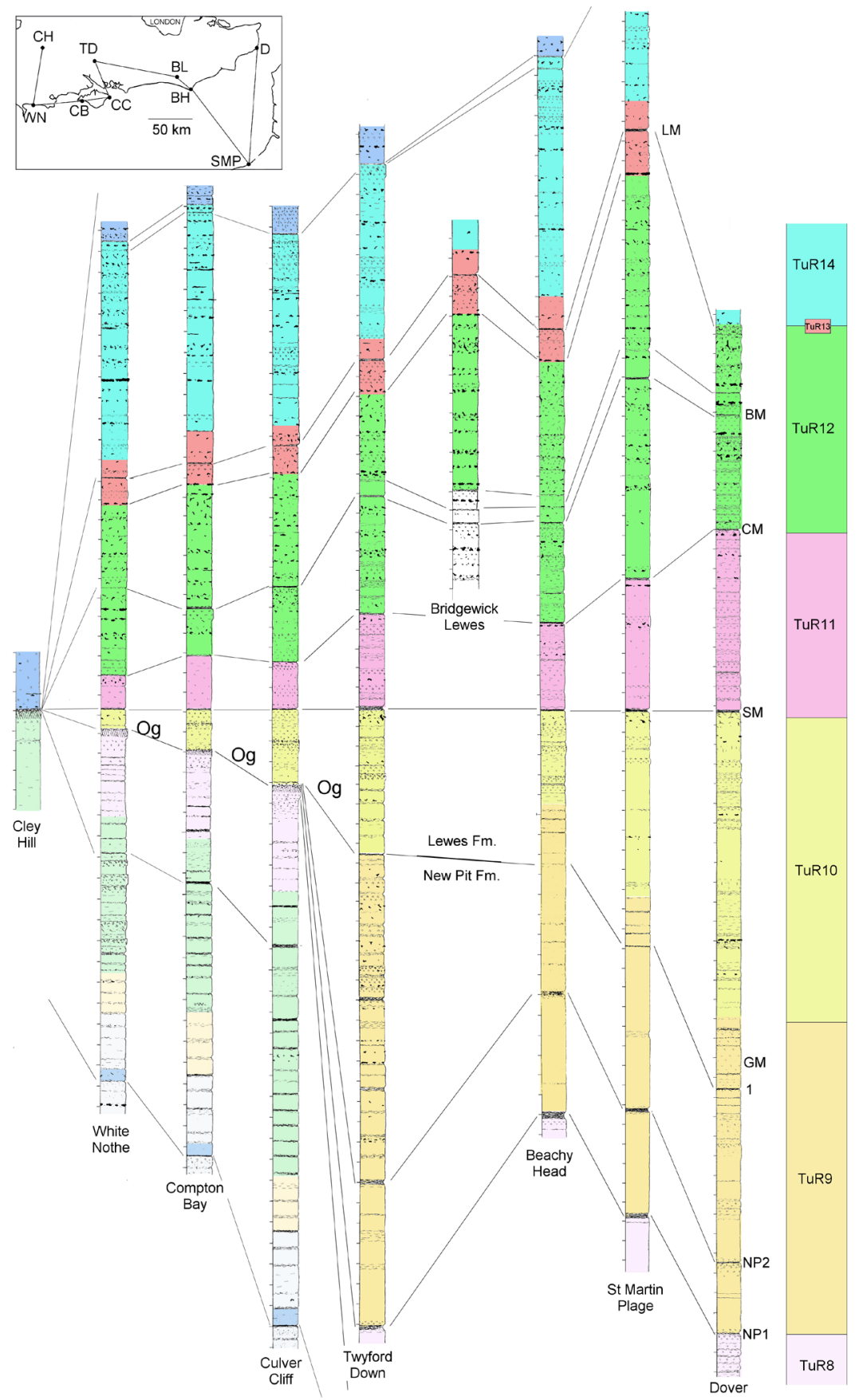

Fig. 5. Middle and Upper Turonian correlation across southern England and Dieppe, France. A complete succession of Middle Turonian is present in basinal localities, including microcrinoid zones TuR6 - 14 (localities 4, 6-8). To the west, the mid-Turonian 
disconformity, represented by the surface of the Ogbourne Hardground, rests on TuR8, and all of zone TuR9, and most of zone TuR10 are missing. At Cley Hill (CH), the entire Upper Turonian is missing and Coniacian chalk (zone CoR1) rests on Middle Turonian (TuR7). Localities; CH, Cley Hill, Wiltshire. WN, White Nothe, Dorset. BH, Ballard Head, Dorset. TD, Twyford Down, M3 cutting, Hampshire. BL, Bridgewick Pit, Lewes, Sussex. BH, Beachy Head, Sussex. SMP, cliffs at St Martin Plage, north-east of Dieppe, Normandy. D, Dover, Kent. The provisional Middle-Upper Turonian boundary is placed at the Caburn Marl. Details of localities in Appendix. Vertical scale in metres. Key to lithological symbols in Fig. 4.

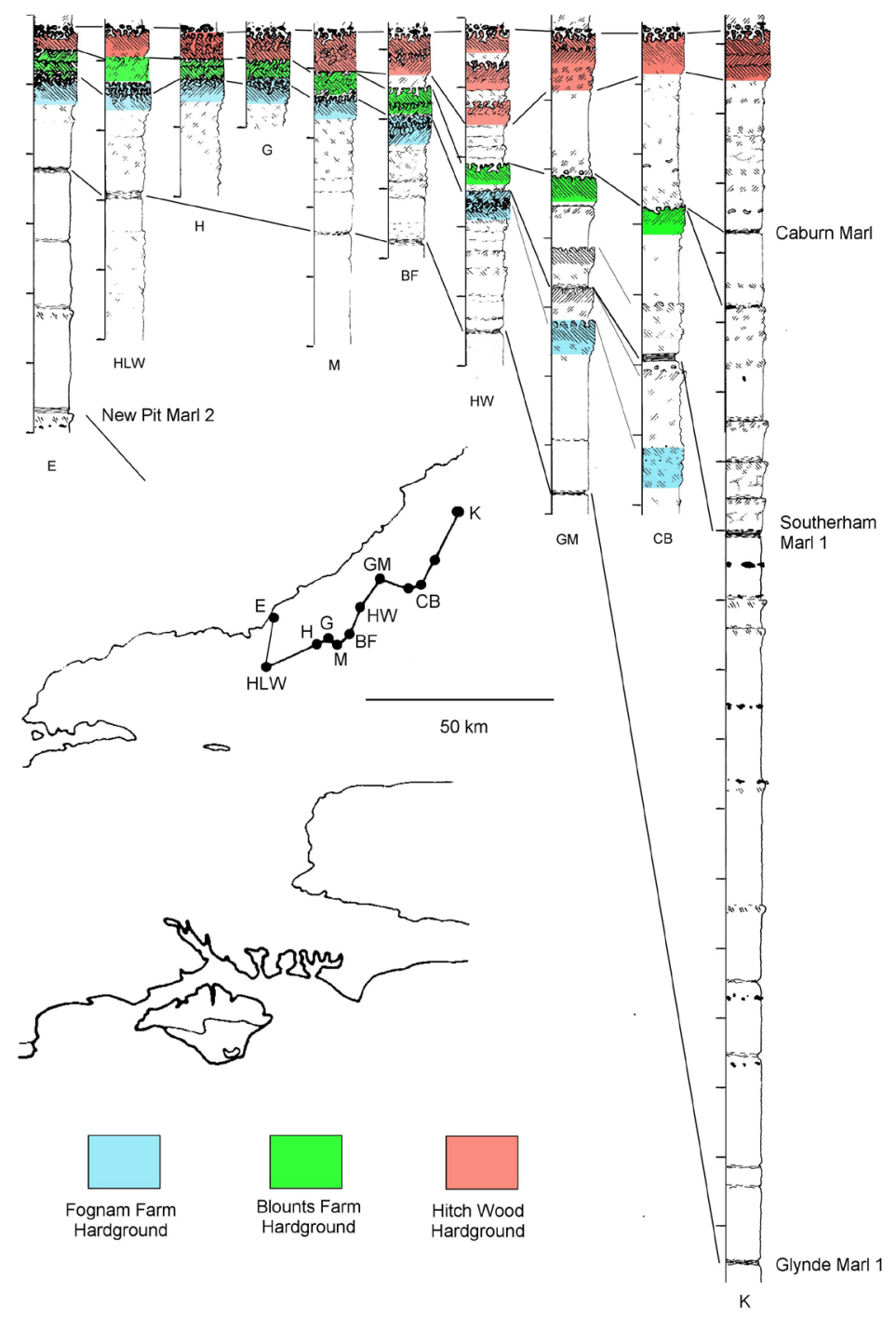

Fig. 6. Correlation of the upper Chalk Rock across the Chilterns. Modified from Bromley and Gale (1982). In the north east, at Kensworth, an expanded succession with marker marls Southerham 1 and Caburn present is developed; only the uppermost hardground, the Hitch Wood, is present. To the south west, the Fognam Farm and Blounts Farm Hardgrounds develop, and the Southerham and Caburn Marls are occluded onto the hardground surfaces. 
All the hardgrounds coalesce in the Henly region to form a composite hardground known as the 'Henly Rock' (Hill, 1886). This progressive condensation is quite different to the erosional nature of the Ogbourne Hardground (see Figs. 5, 6). Localities; E, Ewelme, HLW, Hart's Lock Wood; H, Henly; G, Greenland Farm; M, Medmenham; BF, Blounts Farm; HW, High Wycombe; GM, Great Missenden; CB, Chesham Bois; K, Kensworth. Locality details in Bromley and Gale (1982). Vertical scale in metres. Key to lithological symbols in Fig. 4.

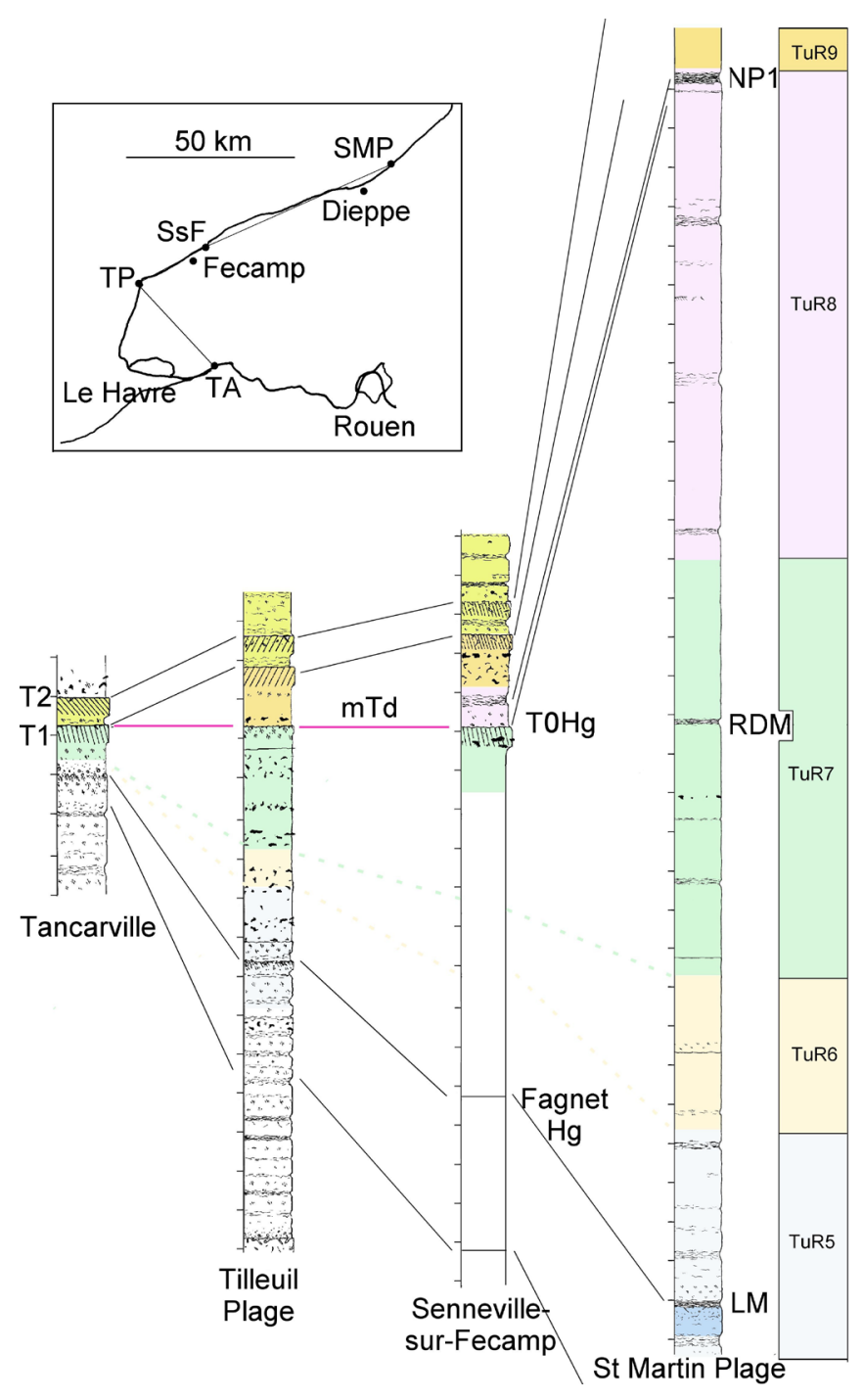

Fig. 7. Correlation of the Middle Turonian chalk, Normandy coast, France. A full succession is present in marly basinal chalks at Dieppe (D) (Gale, 2019). To the west, at Senneville-surFecamp (SsF), a hardground (T0) is present at the summit of microcrinoid zone TuR7, and TuR8 and TuR9 are very thin. At Tilleul Plage (TP), TuR8 is absent. At Tancarville (Ta) the succession is very reduced, and the Tilleul Hardgrounds are only $2 \mathrm{~m}$ above the Filograna avita marker bed. The condensation mirrors that which develops in the Chalk Rock of Wiltshire and Dorset (Figs. 5, 6). Details of localities in Appendix. Vertical scale in metres. Key to lithological symbols in Fig. 4. 


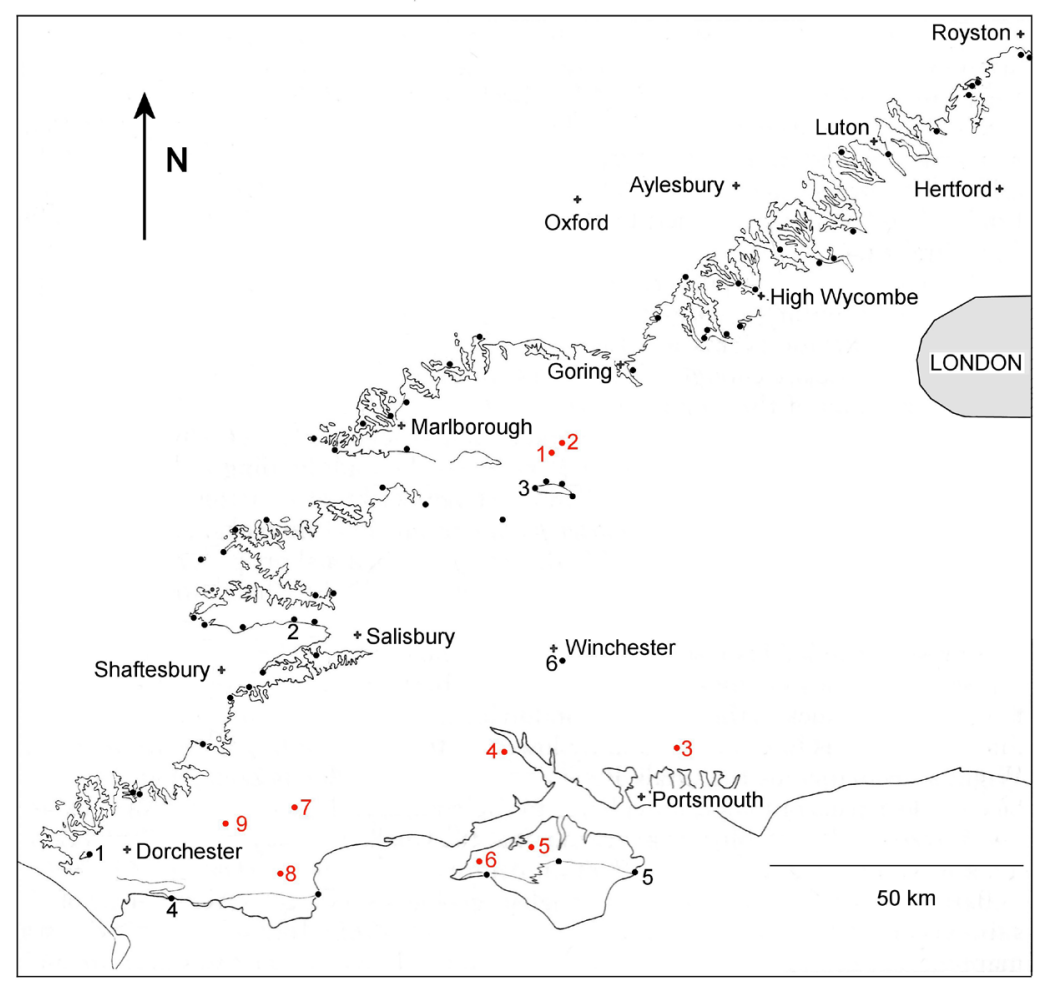

Fig. 8 Map overview of Turonian localities. Line represents approximate Chalk rock outcrop. Dots without numbers represent the localities recorded by Bromley and Gale (1982 fig. 1a), black numbers represent new localities; 1, Loscombe Farm, Winterbourne Abbas, Dorset. 2, roadcut at East Knoyle. 3, road cutting for M3 motorway at Burghclere, Hampshire (Gale 1996). 4, cliff section at White Nothe, Dorset (Gale 1996). 5, cliff section at Culver Cliff, Isle of Wight (Gale 1996). 6, cutting for M3 at Twyford Down, Winchester (Gale 1996). Red numbers refer to boreholes. 1, Banterwick Barn, Berkshire, SU513775. 2, Faircross. Berkshire, SU 697632. 3, Cowplain, Hampshire, 699111. 4, Marchwood no.1, SU440111. 5, Sandhills no. 1, Isle of Wight, SZ406999. 6, Wilmingham. Isle of Wight, SZ366878. 7, Winterbourne Kingston, Dorset, SY847980. 8, Wareham no. 3, Dorset, SY906987. 9, Shapwick no. 1, Dorset, ST 943013. 

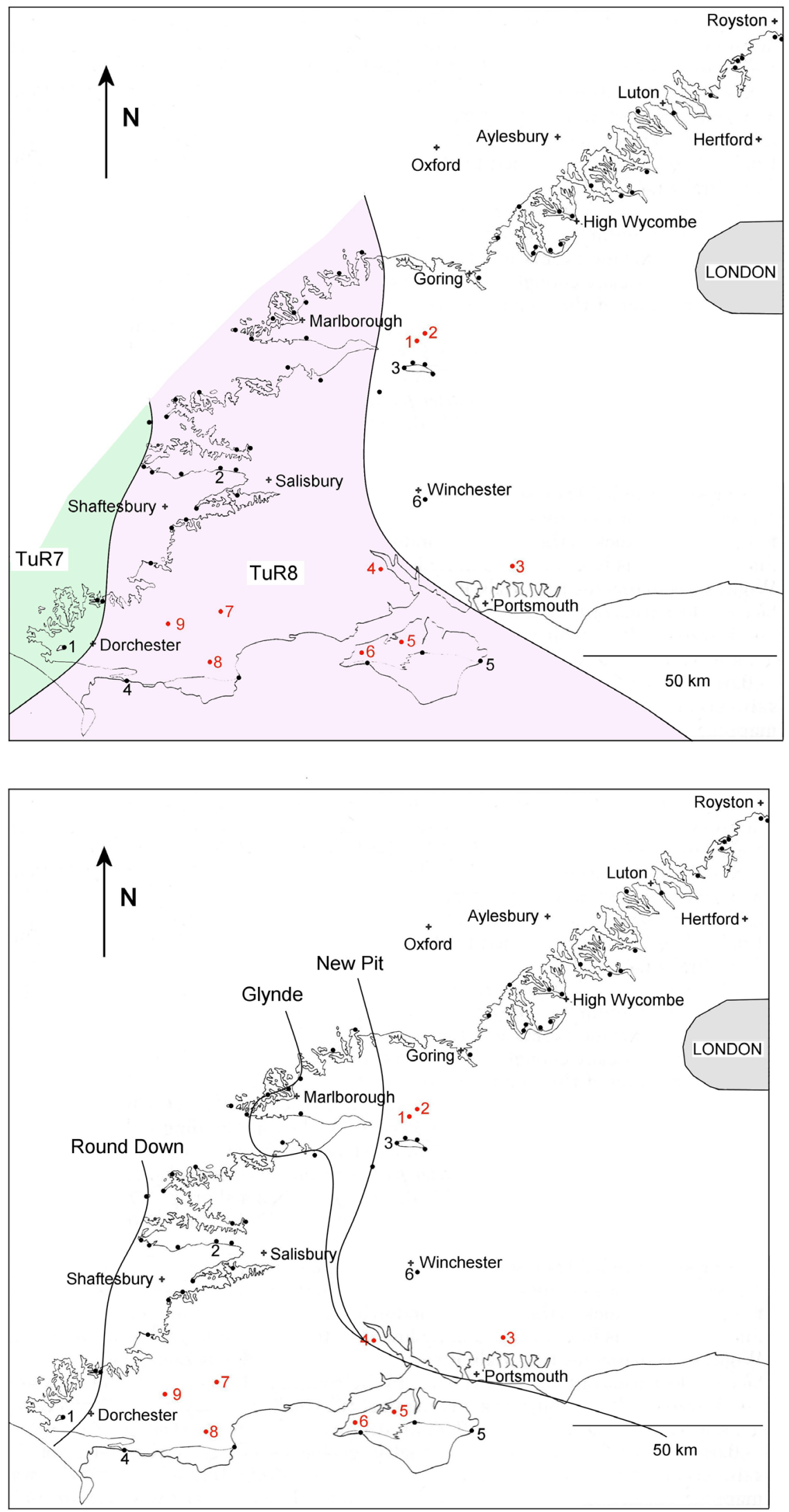

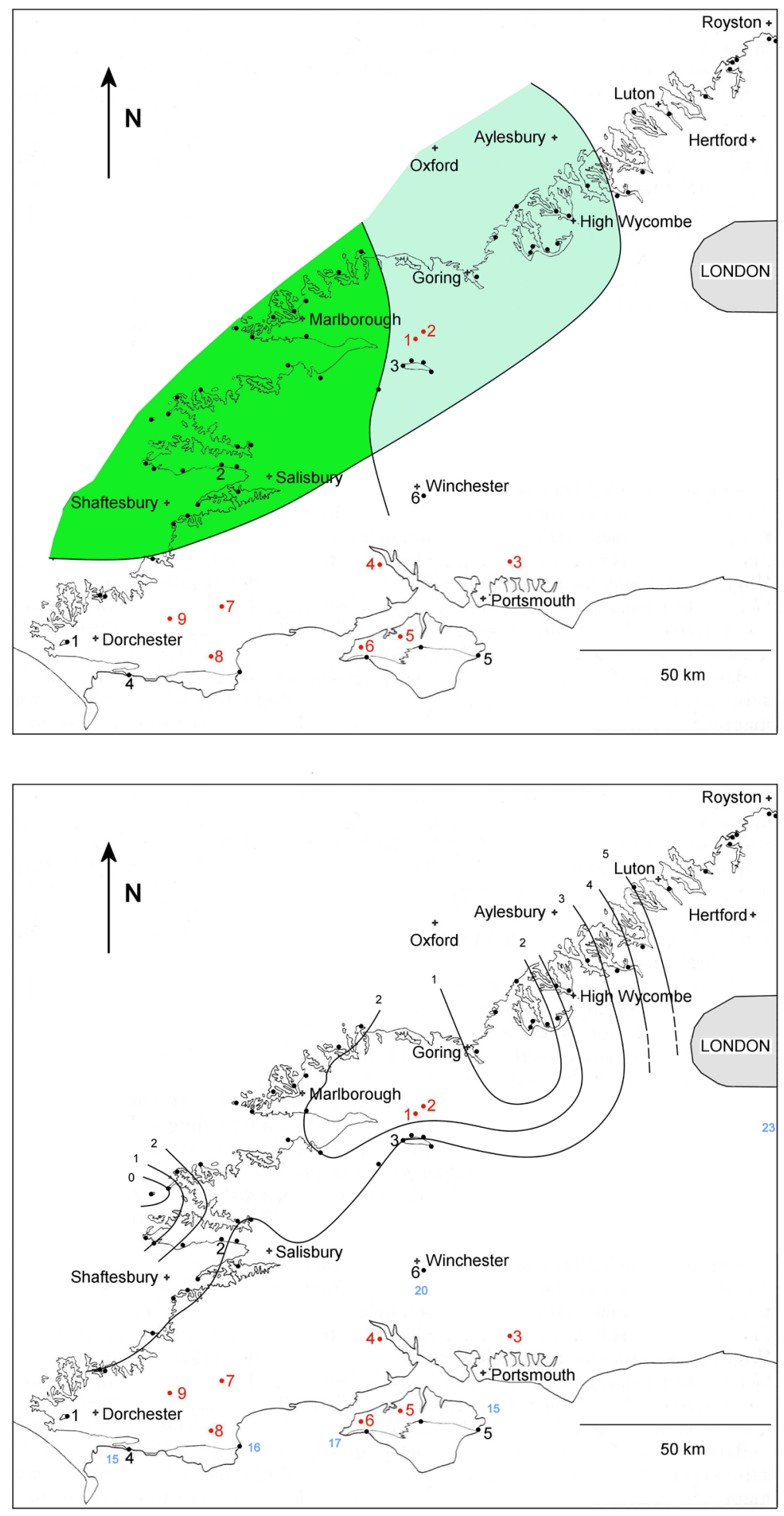

Fig. 9. Maps to show relationships and thickness of the Chalk Rock. A, coloured area represents the extent of the Ogbourne Hardground. The pink region is that in which the hardground lithifies chalk of Zone TuR8 age, and the green where it cuts down to TuR7. To the east, the area in which the Ogbourne Hardground is absent is uncoloured. B, western extent of marls within the New Pit Chalk; successively older levels are cut out beneath or occluded onto the surface of the Ogbourne Hardground to the west. C, extent of the upper part of the Chalk 
Rock (Fognam Farm Hardground to Hitch Wood Hardground) in green. The darker region to the west shows where the Ogbourne Hardground is present, and the Chalk Rock thus represents a significantly greater time interval. D, Isopachs on the upper group of Chalk Rock hardgrounds, Fognam Farm Hardground to Hitch Wood Hardground. Note the extreme condensation north of Shaftesbury, and the thin development west of High Wycombe, where the "Henly Rock" is developed.

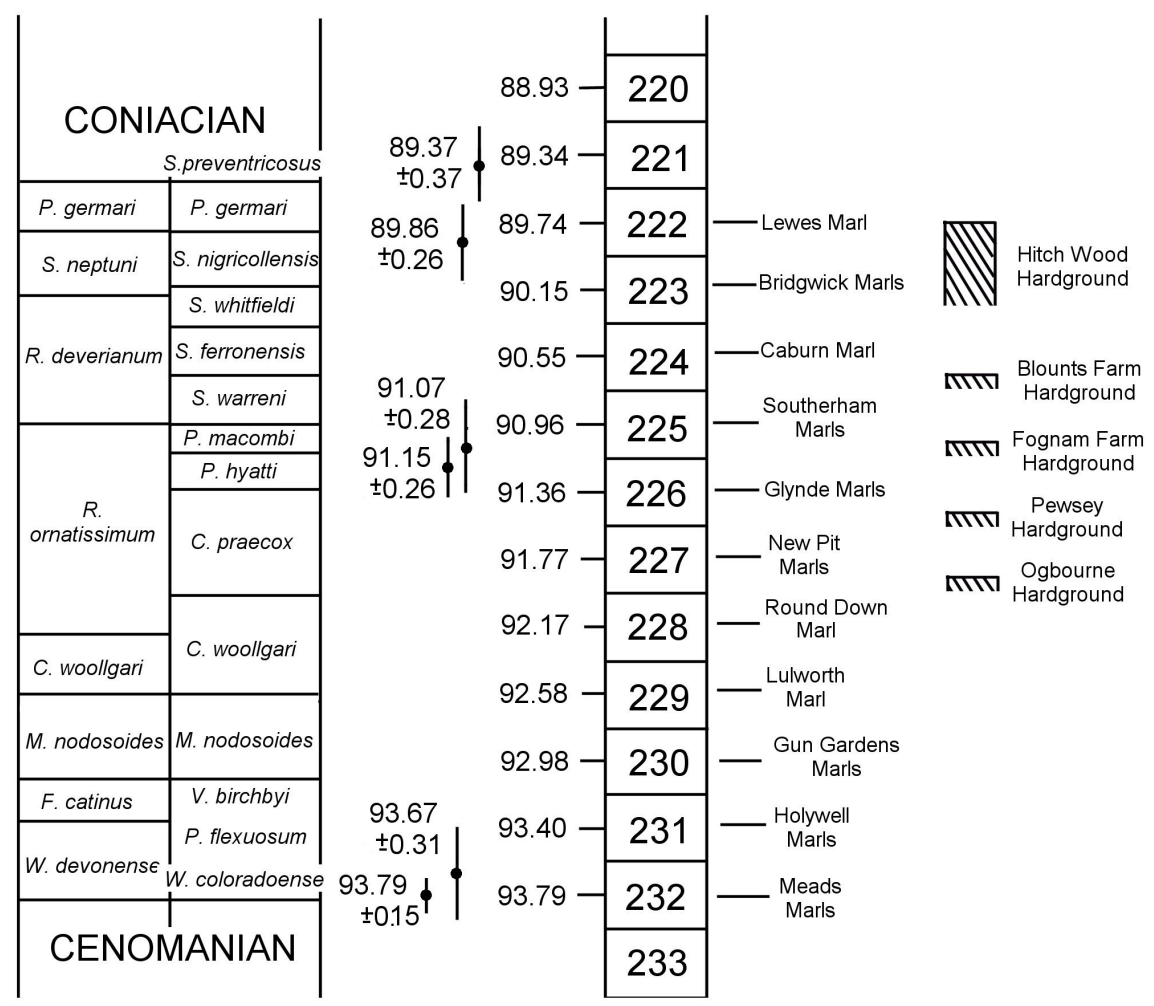

Fig. 10. Proposed cyclostratigraphy and timescale for the Turonian Stage, to show the development of marl:hardground/nodular chalk alternations developed in the Middle and Upper Turonian Chalk of the Anglo-Paris Basin. Based on Laskar et al. (2011) orbital solution for 405Kyr cycles; cyclostratigraphic/radiometric ages for the Lower Turonian from Meyers et al. (2012); radiometric dates from the Western Interior Basin (Gradstein et al. 2012, Appendix 2). Correlation of Western Interior ammonite zones into the Anglo-Paris Basin is based on data in Robaszynski et al. (2014) from Uchaux, southern France, which permits correlation of the Prionocyclus hyatti and P. germari Zones into European successions. It is inferred that intervals with marl beds reflect $405 \mathrm{Kyr}$ eccentricity maxima, and nodular chalks and hardgrounds represent minima. 


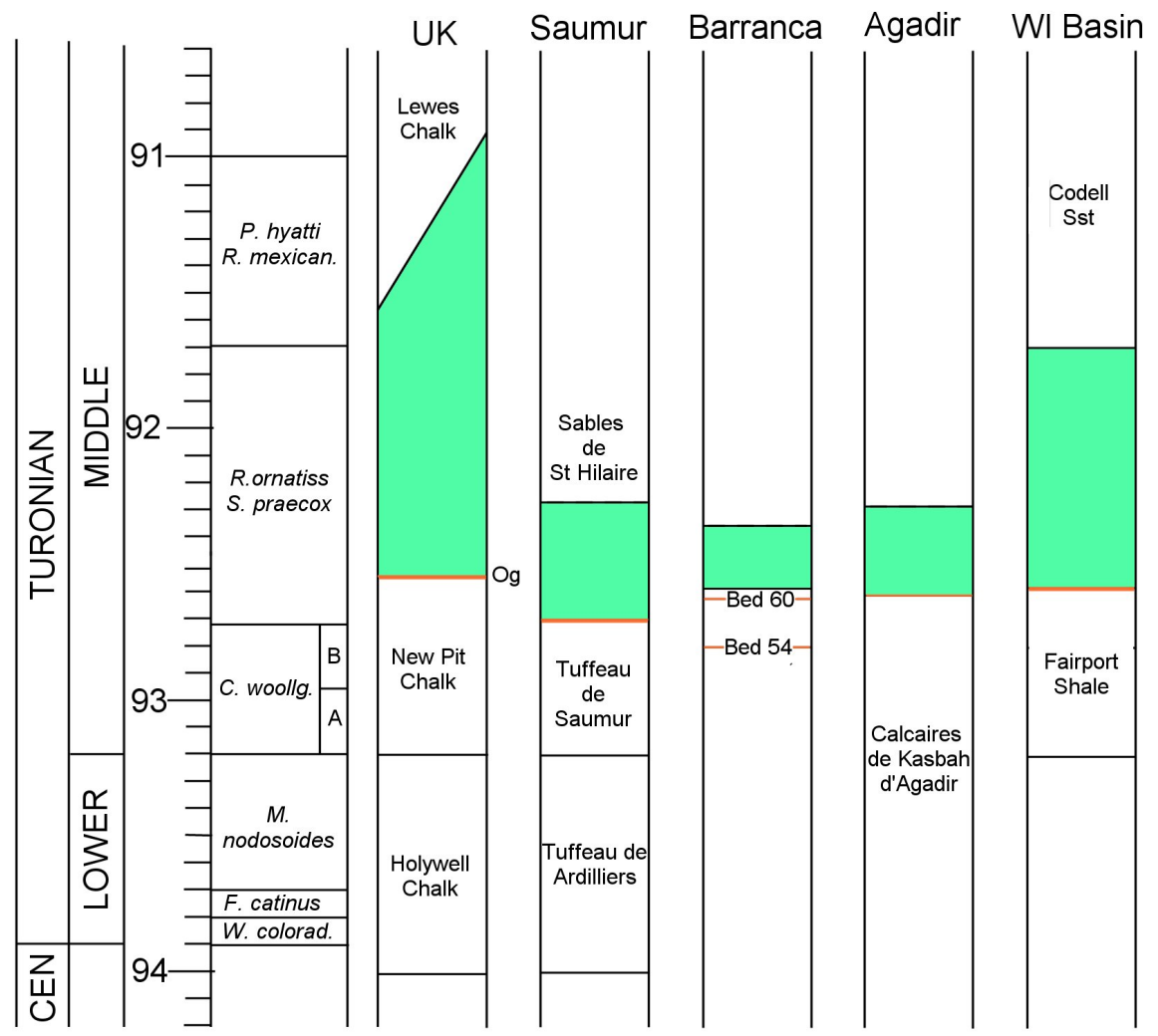

Fig. 11. Global correlation of the mid-Turonian disconformity. UK, this paper and Gale (1996); Saumur, France, after Amédro et al. (2018); Barranca, northern Spain, after Küchler (1998); Agadir, Morocco, Gale pers. obs.; Western Interior Basin, USA, after Joo and Sageman (2014). Note that the erosional event is within the lower part of the Romaniceras ornatissimum Zone or its correlative, but that sedimentation does not recommence locally until much later. 